\title{
Identifying intergroup threats in the attitudes of young Slovaks toward ethnic minorities
}

\author{
DóRA BELÁN
}

Institute for Research in Social Communication, SAS, Dúbravská cesta 9, 84104 Bratislava 4, Slovak Republic, dora.belan@savba.sk

\section{Miroslav Popper}

Faculty of Social and Economic Sciences, Comenius University in Bratislava, Mlynské luhy 4, 82105 Bratislava, Slovak Republic, miroslav.popper@fses.uniba.sk

\begin{abstract}
Perceived threats from out-groups play a significant role in negative intergroup relations. The aim of our study was to explore what types of threats young Slovaks feel from three out-groups: immigrants from African and Arab countries, the Roma, and Slovak Hungarians. By conducting six focus groups $(N=42)$ with university students $(M=22)$, we identified several concerns about these out-groups. We found out that they can be categorized into four threat types in line with Stephan et al. (2009): (1) symbolic group threats, (2) symbolic individual threats, (3) realistic group threats, and (4) realistic individual threats. However, we identified threats which have not been identified in previous threat literature, e.g. language barrier, sexual harassment, and annoyance, or were not researched as threat, e.g. theft, abuse of social system, and lack of trust. Therefore, we aim to develop a new measure which allows researchers to focus on a broader scale of perceived threats in prejudice reduction. As we have explored different concerns posed by different out-groups, we argue that in prejudice reduction it is important to focus on those threats that are felt by the majority from a particular out- group, and not to perceive intergroup threat as one general factor.
\end{abstract}

Keywords: intergroup threat; attitudes; ethnic minorities; university students

\section{Introduction}

In Slovakia, there are three most-discussed minority groups: the Roma, Slovak Hungarians, and immigrants. While the attitudes of Slovaks towards these out-groups are different (see Gallová Kriglerová \& Kadlečíková, 2012; Macháček, 2013), each of these minorities raise some unique concerns. Concerns about out- groups fall within the concept of intergroup threat (Stephan et al., 2009). Since perceived threat is an important predictor of negative attitudes (Jedinger \& Eisentraut, 2020; Riek et al., 2006; Stephan, 2014), it is crucial to understand the types of threats that minority groups trigger for the majority population. Accordingly, the aim of the present research is to identify what types of threats are felt by young Slovaks from the Roma, Slovak Hungarians, and immigrants from African and Arab countries.

\section{Threat types}

Ethnic minorities and immigrants are often portrayed as threats, as a potential danger to society (Van der Linden \& Jacobs, 2016). The intergroup threat theory (Stephan et al., 2009) assumes that other groups are frequently perceived by the majority as a threat to their beliefs, values, and culture (symbolic threat), or their power, resources, and safety (realistic threat). Researchers focus on the perceived threats because the perception of a threat can lead to prejudices regardless of whether the threat is real. The greater the sense of threat that an individual or group perceives from an out-group, the more negative attitudes will be towards that group (LeVine \& Campbell, 1977). The original theory, i.e. the integrated threat theory (Stephan \& Stephan, 2000) classified threats into four types: (1) realistic threats, (2) symbolic threats, (3) intergroup anxiety, and (4) negative stereotypes. However, further research has found that these four types of threats are not equal as factors, because negative stereotypes are rather important predictors of both realistic and symbolic threats (Stephan et al., 2002), and intergroup anxiety is a consequence of threat (Stephan et al., 2009).

The intergroup threat theory (Stephan et al., 2009) yet divides threats into four categories according to whether the threat affects a particular person or its entire in-group. The types of perceived threats are therefore the follows: (1) realistic individual threats (perceived threats to physical or material damage to an individual such as a threat to personal security or 
economic loss); (2) symbolic individual threats (concerns about the loss of a face or honor and the weakening of an individual's personal identity or self-esteem); (3) realistic group threats (perceived threats to the group's power, resources and the general well-being); and (4) symbolic group threats (threats to the group's culture, religion, values, beliefs, morality, or worldview).

Even though studies have mostly examined threats through the lens of realistic and symbolic group threats, other threat types can also be posed by out-groups. Research identifies distinctiveness threat (Jetten et al., 1997), concerns about criminal behavior that pose safety threats, threat to social cohesion/coordination (Cottrell \& Neuberg, 2005; Landmann et al., 2019), threat of terrorist attacks (Cohrs et al., 2005), threats due to lack of jobs and social services, e. g. economic threat (Schneider, 2008), health threat, threat to rights and freedom (Cottrell \& Neuberg, 2005), prejudice threat, and the altruistic threat (Landmann et al., 2019). Since there are various threat feelings, it is important to explore what types of concerns are posed by which minority group. Nevertheless, many of these threats can be included into the intergroup threat theory, e. g. criminal behavior, terrorist attacks and economic threats belong into realistic threats, while the threat to social cohesion belongs to symbolic threats.

The relationship between perceived threat and negative attitudes is well established and supported by metaanalytical findings (Riek et al., 2006), but Stephan et al. (2009) point out behavioral and emotional consequences as well. Behavioral consequences range from avoidance, submission, aggressive statements, defamation, lies, to discrimination, harassment, retaliation, protests, wars, and other forms of open conflict between groups. Cakal et al. (2016) confirmed that perceived threats can also motivate to engage in collective action among advantaged and disadvantaged groups. Emotional responses can be anger, fear, anxiety, contempt and disgust, hatred, humiliation, helplessness, despair, and panic (Stephan et al., 2009). Threat can also evoke moral emotions like compassion and guilt (Landmann et al., 2019). Neuberg and Cottrell (2002) argue that specific types of threats are associated with specific emotions. Perception of a threat can also weaken the sense of empathy for the members of the out-group and increase empathy for individuals from one's in-group (Leach et al., 2003). Because perceived threats can have many negative consequences, it is important to recognize the types of threats the majority feel from minorities in order to combat them.

\section{Threats posed by ethnic minorities in Slovakia}

Based on the results from the Special Eurobarometer on discrimination (2019), Slovak attitudes towards various minorities and perceived discrimination in Slovakia are far worse than the average rate of the European Union. Negative attitudes and prejudices are widespread, especially towards Roma people and immigrants, particularly Muslims (e.g. Bieliková et al., 2013; Gallová Kriglerová \& Kadlečíková, 2012; Kalmárová et al., 2017; Slovíková, 2012).

Although attitudes of Slovaks toward the Slovak Hungarians are not so extreme, negative intergroup attitudes are also present here (e.g. Gallová Kriglerová, 2009; Gallová Kriglerová \& Kadleč́íková, 2012).

According to Macháček (2013), Slovaks divide these minorities into distinct categories on social distance scale: with Hungarians they are open to even personal contact, with immigrants they are open to only live in the same state, while in case of the Roma they feel aversion. In research by Gallová Kriglerová and Kadlečíková (2012), young Slovaks strongly supported restrictive policy towards the Roma minority, which denies fundamental equality of rights and is openly discriminatory; in relation to the Hungarian minority, more than a third of the respondents declared that Slovak Hungarians should not speak in Hungarian in public and that their ethnic identity should be fulfilled only in a private space; in relation to immigrants participants from majority largely claimed that they should keep their culture private; and marked that the state should not allow Muslims to practice their faith. Furthermore, Slovaks feel various concerns and threats from these minorities (Bahna \& Klobucký, 2015; 2016; Benkovičová, 1995; Lášticová \& Andráščiková, 2016; Pétiová, 2016; Vašečka, 2009).

\subsection{Threats from migrants/refugees}

After the EU migration crisis in 2015, migration was at the forefront of political discourse, which led to growing sense of perceived threat and to an increase of negative attitudes and intergroup hostility toward immigrants in many European countries. Slovakia is one of the countries where attitudes towards immigrants had been saturated with stereotypes about crime and terrorism, which evoke fear and a perception of threat to personal safety (Bahna \& Klobucký, 2015, 2016; Lášticová \& Andráščiková, 2016; Pétiová, 2016). There are also concerns about the reluctance of immigrants to adapt to the Slovak culture and way of life (symbolic threats), as well as economic threats, e.g. that refugees will cost the state too much money (Bahna \& Klobucký, $2015,2016)$. It has been confirmed by many studies that the perception of symbolic and realistic threats posed by immigrants are the main cause of negative attitudes and feelings towards them (e. g. Esses et al., 2017; Stephan et al., 2005; Yitmen \& Verkuyten, 2018; Zárate et al., 2004), and also encourages prejudice and discrimination against them (Schlueter \& Scheepers 2010). As Slovaks have the most negative attitudes towards Mus- 
lim immigrants (Gallová Kriglerová \& Kadlečíková, 2012), in our research we explored threats only posed by immigrants from Arab and African countries.

\subsection{Threats from Roma minority}

The Roma minority is also subject to stigmatization, dehumanization, and blatant prejudice (Kteily et al., 2015). Research suggests that the perception of the Roma through 'otherness' may be the key to prejudices towards them (Petrova, 2003). Kende et al. (2020) found that in Slovakia (and other countries) anti-Gypsyism is shaped by 1) traditional stereotypes about the laziness and criminality of Roma people, e. g. blatant negative stereotyping, 2) the idea of Roma receiving undeserved benefits, and 3) lack of cultural recognition. The belief that the Roma have different culture, values, norms, ways of life, and cannot adapt to mainstream society (Richardson, 2006) can be interpreted as symbolic threat, the undeserved benefits can be linked to economic threats (realistic group threat), while the universal belief that the Roma are criminals and fraudsters (Goldston, 2002), poses safety (realistic) threats. Dimitrova et al. (2015) confirmed that the perceived economic, symbolic, and safety threat posed by the Roma was closely related to the level of prejudice of Romanian and Bulgarian youth to them. Other studies also supported evidence that negative emotions and negative attitudes towards Roma people are closely related to the realistic and symbolic threat (e.g. Hutchison et al., 2018; Ljujic et al., 2012).

\subsection{Threats from Slovak Hungarians}

Slovak Hungarians are not as much of a prejudiced minority in Slovakia than the Roma or immigrants as a whole. They have a similar standard of living as Slovaks, have an extensive Hungarian language school system, ethnic political parties, and cultural, political, and economic support of their national state of Hungary (Stroschein, 2018). There is minimal literature about the threats posed by this out-group. Benkovičová (1995), for example, noted that some Slovaks perceived Hungarians as threatening, because of their 'dissatisfied' nature. More people said that they 'do not respect Slovakia,' 'they want more rights than Slovaks' and felt a territorial threat from Slovak Hungarians. Due to the shared past between Slovaks and Hungarians, Slovaks may perceive territory and power threats to their own group. In a study carried out by Gallová Kriglerová \& Kadlečíková (2009), negative statements by Slovaks about the Slovak Hungarians included statements about historical guilt, oppression by Hungarians, or interest in Slovak territory. The Hungarian minority could pose symbolic threats as well, since negative attitudes of Slovaks towards this minority are related mainly to the use of Hungarian language in public (Gallová Kriglerová \& Kadleč́íková, 2012).
Perceived threats to the in-group in contexts where prejudices are normatively accepted are associated with prejudices and discriminatory behavioral intentions of members of the majority (Kende et al., 2017; Minescu et al., 2008). This holds for Slovakia and therefore it is important to address intergroup relations based on intergroup threat theory (Stephan et al., 2009).

\section{The present research}

The aim of the research was to identify what types of threats are felt by young Slovaks from three ethnic minorities: the Roma, Slovak Hungarians, and immigrants from Arab and African countries.

\subsection{Methods}

Participants were recruited via social media using convenience sampling. The research group consisted of Slovak university students $(N=42)$ aged 19 to $25(M=22)$. Arnett (2004) characterizes this life period as emerging adulthood wherein young people can explore their identity, which allows experimentation in the intimate, professional, and worldview side of life, and shapes their intergroup attitudes.

We conducted focus group discussions via MS Teams through the months of May, June, and July 2020. There were six focus groups (in each $n=7$ ). Two group interviews explored threats posed by the Roma, two by Slovak Hungarians, and two by immigrants from African and Arab countries (see Table 1). Therefore, fourteen participants discussed attitudes and perceived threats from the Roma, fourteen from Slovak Hungarians, and fourteen from immigrants.

Table 1: Focus group discussions about perceived intergroup threats

\begin{tabular}{lrr} 
Focus group & Contact & $N=42$ \\
\hline Focus group discussion about the Roma & with contact & $n=7$ \\
& without contact & $n=7$ \\
Focus group discussion about Slovak Hungarians & with contact & $n=7$ \\
& without contact & $n=7$ \\
Focus group discussion about immigrants & with contact & $n=7$ \\
from Arab and African countries & without contact & $n=7$
\end{tabular}

We followed the rules of Plichtová (2002) concerning the heterogeneity between groups and the homogeneity within groups, and thus divided the participants into group discussions based on their contact with members of the minority group. This way we could examine the attitudes and interpretations of both those who are, and those who are not, in direct contact with members of the discussed minority. Keil et al. (2020) state that traditional forms of contact, such as verbal, personal contact with acquaintances, friends, and family are 
generally defined as contacts. We measured contact with two questions: (1) frequency of spending time and (2) frequency of communication with members of the discussed minority group. Those who answered that they have daily and weekly contact and communication with members of the minority participated in one focus group, while those who answered that they have no or yearly contact and communication with the minority which was discussed, participated in another focus group. We must add that some participants in the focus group without direct contact with the Roma mentioned some previous experiences because they live in villages where Roma members also live. However, based on the findings of Keil et al. (2020), we decided to not count meeting strangers in public as direct contact. In focus groups, we asked three basic questions:

1. How do you personally perceive the Roma / Slovak Hungarians / immigrants from African or Arab countries?

2. According to you, what are the positives and negatives of the Roma / Slovak Hungarians / immigrants from African or Arab countries?

3. Do you have any concerns from the Roma / Slovak Hungarians / immigrants from African or Arab countries? Do you feel any threat from them? If so, what are those concerns, threats?

We also asked additional questions prompting the discussion if necessary.

Focus groups lasted from forty-five minutes to one and a half hours. After the data was transcribed, we analyzed the discussions through thematic-content analysis (Joffe \& Yardley, 2004). The first step was to encode a large amount of complex data. The relevant phrases and sentences were selected from the texts, then we formed categories, super-categories, and finally included the threat types into thematic areas. Exploring the different threat types by content analysis was a bottom-up process, the last step - including the particular threat types into broad thematic areas - was a top-down procedure, i.e. we checked whether broad categories of threat proposed by Stephan et al. (2009) could be useful. We also counted the frequency that the codes occurred in group discussions.

\section{Results}

Using qualitative methods, we identified several types of threats that young Slovaks experience. Although most of the identified concerns from the out-groups have been examined by previous authors, we explored some threats which are not covered in earlier literature. All the new threats were possible to categorize into four groups based on Stephan et al. (2009): (1) symbolic group threats, (2) symbolic individual threats, (3) realistic group threats, and (4) realistic individual threats.
While some threat types can be related to each minority, some of them occurred only in relation to one or two out-groups.

\section{(1) Symbolic group threats}

Symbolic group threat to culture, norms, values, or way of life was mentioned by several participants and is perceived from each out-group (see Table 2). There was no difference in statements whether the participant had contact with minority members or not.

Table 2: Number of participants perceiving symbolic group threats from examined out-groups

\begin{tabular}{|c|c|c|c|}
\hline & $\begin{array}{c}\text { Immigrants } \\
(n=14)\end{array}$ & $\begin{array}{c}\text { Roma } \\
(n=14)\end{array}$ & $\begin{array}{l}\text { Hungarians } \\
(n=14)\end{array}$ \\
\hline $\begin{array}{l}\text { Symbolic } \\
\text { group }\end{array}$ & with contact: 2 & with contact: 2 & with contact: 3 \\
\hline
\end{tabular}

Concerns about immigrants were mostly related to a threat to one's own culture and cultural adaptation: 'we never know if they would build mosques and change the culture here' (woman 5, age 19, without contact) or 'I see that they cannot or do not want to fully adapt, a friend himself told me that they have it so deeply ingrained in themselves, they are proud to be Arabs' (woman 1, age 22, with contact). In the case of the Roma, symbolic group threats concerned the different way of life or living standards as Slovaks have: 'the child sees, from those parents or members of the community, so they think it's normal that they live in dirt in the settlements and they are rude' (woman 7, age 23, with contact) or 'not lazy, but indifferent to what is actually going on there, that they are throwing trash there and it is okay, they do not want to adapt, because our state creates conditions for them when they do not have to adapt and change' (man 2, age 22, without contact). Finally, concerns about Slovak Hungarians were mainly about the lack of language adaptation: 'For example, I was annoyed by the billboards of some political parties in Hungarian language, because maybe, even if I wanted to vote for them, it would make me angry as Slovak that they give billboards purely in Hungarian' (woman 1, age 21, with contact) or 'I also read that they are in favor of having a high school final tests in Hungarian or something like that, they don't want to adapt to the fact that they live in Slovakia' (woman 5, age 22, without contact).

\section{(2) Symbolic individual threats}

Although symbolic individual threats are described as concerns about the loss of honor, and the weakening of an individual's identity, we added language barrier and trust problems to this category (see Table 3). The rationale is that these both trigger uncertainty and some level of anxiety at the individual level. Based on our 
knowledge, language barrier has not been mentioned in literature yet as a threat type.

Table 3: Number of participants perceiving symbolic individual threats from examined out-groups

\begin{tabular}{|c|c|c|c|}
\hline $\begin{array}{l}\text { Symbolic } \\
\text { individual } \\
\text { threats }\end{array}$ & $\begin{array}{l}\text { Immigrants } \\
\qquad(n=14)\end{array}$ & $\begin{array}{l}\text { Roma } \\
(n=14)\end{array}$ & $\begin{array}{l}\text { Hungarians } \\
\qquad(n=14)\end{array}$ \\
\hline $\begin{array}{l}\text { Language } \\
\text { barrier }\end{array}$ & - & - & $\begin{array}{l}\text { with contact: } 4 \\
\text { without contact: } 2\end{array}$ \\
\hline ust & without contact: & $\begin{array}{l}-- \\
-\end{array}$ & - \\
\hline
\end{tabular}

While participants (regardless of contact) tend to connect language barriers only with Hungarians, lack of trust occurred only in the focus group about immigrants from Arab countries. Language barriers can be interpreted as anxiety or anger because participants from the majority have difficulties to communicate with Slovak Hungarians, when they prefer to speak in Hungarian or cannot properly speak in the Slovak language. This category is illustrated by the following quotations: 'I used to live with two girls who knew Hungarian, so they still only spoke Hungarian, even though I was there, which is quite unpleasant' (woman 4, age 23, with contact) or 'we wanted to ask about the route in Štúrovo [city in south Slovakia next to the Hungarian border] and the man didn't understand us at all, so it seemed so weird to me then that he didn't really understand Slovak and lives in Slovakia' (man 2, age 21, with contact). Trust issues concerned the generalization of Arab culture as dangerous by participants with no contact with this out-group: 'that I'm afraid of that culture, so if I would notice a dangerous type of behavior, I would be vigilant right away and maybe I would judge other people from that culture in the same way' (woman 6, age 22, without contact).

\section{(3) Realistic group threats}

Realistic threats which affect the entire in-group include the same threat types as described in the intergroup threat theory: economic and power threats (see Table 4). The identified threats to the economy are the following: lack of jobs, demands on territory, and abuse of the social system.
The threat to jobs was feared by a participant from focus group about immigrants who had no contact with this minority: 'so I would certainly be afraid of the changes that will come, or could come, in the laws that affect the economy, or then the number of jobs because they would work in our country, it would affect the overall economy' (woman 7, age 21, without contact) and a participant without contact with Slovak Hungarians: 'I am a little saddened by the fact that if you currently apply for a job in Bratislava or Nitra, without Hungarian language there is almost no one left' (woman 7, age 24, without contact). One participant in no contact with Slovak Hungarians mentioned territorial threat: 'the people concerned may take a negative view that they occupy their territory in Slovakia, even if they are not Slovaks and especially when they do not even plan to learn our language' (woman 3, age 20, without contact). The most important category within threats to the economy was the abuse of the social system. Some participants have concerns about social system abuse from immigrants: 'what would bother me is if they came here and didn't work, didn't support our state when they moved here' (woman 6, age 25, with contact). Abuse of the social system is the only economic threat perceived from the Roma: 'in general, the Roma complain that they have no money and they get money from the state, while not trying to work' (woman 1, age 20, without contact).

Interestingly, power threats were mentioned only in focus group discussions about Slovak Hungarians. Power threats are perceived both by those with contact, and without contact with members of this minority. Some statements were related to political power: 'I perceived that they tried to push into Slovak politics, and they were also active in it, but I don't understand why' (woman 5, age 22, without contact). Other threats were from Hungarian power as general, mainly based on common history: 'Slovakia is still a state not very confident, of course, the past, the oppression also from the Hungarian, so maybe people are afraid that it will start changing to Hungarian Slovakia here' (woman 2, age 23, without contact) or 'not on the territory of the whole Slovakia, but in those villages in the border areas the Hungarian culture can prevail, but the threat actually stems from the historical point of view that, as technically,

Table 4: Number of participants perceiving realistic group threats from examined out-groups

\begin{tabular}{|c|c|c|c|c|}
\hline Realistic group threats & & $\begin{array}{l}\text { Immigrants } \\
(n=14)\end{array}$ & $\begin{array}{l}\text { Roma } \\
(n=14)\end{array}$ & $\begin{array}{l}\text { Hungarians } \\
\quad(n=14)\end{array}$ \\
\hline \multirow{4}{*}{ Threats to economy } & Lack of jobs & without contact: 1 & - & without contact: 1 \\
\hline & Demands on territory & - & - & without contact: 1 \\
\hline & Abuse of social system & with contact: 2 & with contact: 2 & \multirow{2}{*}{-} \\
\hline & & without contact: 1 & without contact: 2 & \\
\hline Threats to power & & - & - & $\begin{array}{c}\text { with contact: } 3 \\
\text { without contact: } 3\end{array}$ \\
\hline
\end{tabular}


we have long been under the domination of Hungarians' (woman 6, age 20, with contact).

\section{(4) Realistic individual threats}

This category includes perceived threats to physical or material damage to an individual (see Table 5). We explored some types of concerns such as theft, sexual harassment, and annoyance, which were not examined in threat theory studies up to now. We identified many categories which are posed by immigrants from Arab and African countries and the Roma, according to Slovak participants. Realistic individual threats are not perceived from Slovak Hungarians.

Realistic individual threats posed by immigrants from Arab and African countries were perceived mostly by Slovaks without contact with them. Threats of terrorist attacks were expressed as follows: 'overall, we may be afraid of some people who are Muslims because of those terrorist attacks and explosions for religious reasons' (woman 2, age 21, without contact). Many concerns related to a stereotypical view of immigrants as criminals, which is portrayed by the media: 'I think that's what they're talking about, and I think some may be more aggressive and therefore the rise of criminality' (woman 4, age 22, without contact) or 'the media has perhaps given me such a negative attitude towards these people, or perhaps such vigilance or paranoia that they will do something wrong to us or that they are worse than us' (woman 1, age 21, without contact). Safety threats and sexual harassment were mentioned by a participant who had no contact with members of this minority: 'I would also be afraid of the large number of people I would meet on the street in the evening, but this is related to my experience in Ukraine, where there are quite a few immigrants and it is dangerous to go outside alone in the evening' (woman 2, age 21, without contact). The last threat type posed by immigrants is theft, which can be illustrated with the following quotation: 'so according to those stereotypes, I was worried at the bus station, and I felt so tense about my things, that they could accidentally disappear' (woman 5, age 19, without contact).

Many participants had realistic individual concerns posed by the Roma. The stereotypical criminality was mentioned once: 'mostly from television they form such an opinion about them that we form such an opinion that they are sometimes a group of people difficult to control, and therefore it simply arouses fear' (woman 6, age 21 , without contact). Real safety threats were explored in many statements, e. g.: 'The Roma began to beat and threaten other participants in the event. They threw benches at the stalls where we worked and where people sat. They tore up the fence and threw it to a new tent, which they completely demolished' (man 4, age 22, without contact) or 'that negative behavior, as some are used to behave and thus manifest themselves more aggressively' (woman 6, age 21, without contact). The threat of theft posed by the Roma was identified only in the focus group of Slovaks without direct contact with this minority: 'When I go somewhere, a Roma stops me and asks what time it is, so the suspicion is automatic, but of course he won't steal from me in broad daylight, and when they are asking for money and such, and it causes such a fear that you start checking your wallet' (man 7 , age 25, without contact). Sexual harassment as a concern was also perceived by some respondents: 'Whenever I go out and they are in some group they start to look at me like I am a piece of meat, it's very annoying and they don't look away. They say something and you have no idea what. Sometimes I'm even afraid that they will come to me and demand something' (woman 3, age 23, with contact). Harassment of a nature more like annoying or bothering other people was mentioned by many majority participants: 'I don't like that they try to coax or the example that they want to read your fortune, in general I don't like the fact that someone else is bothering me' (woman 1, age 20, without contact) or 'especially my own experience with noise, that I meet more noisy and annoying Roma than whites' (woman 3, age 23, with contact).

Table 5: Number of participants perceiving realistic individual threats from examined out-groups

\begin{tabular}{|c|c|c|c|}
\hline Realistic individual threats & $\begin{array}{l}\text { Immigrants } \\
\quad(n=14)\end{array}$ & $\begin{array}{l}\text { Roma } \\
(n=14)\end{array}$ & $\begin{array}{l}\text { Hungarians } \\
\quad(n=14)\end{array}$ \\
\hline Terrorist attacks & without contact: 2 & - & - \\
\hline \multirow{2}{*}{ Criminality } & with contact: 1 & & \multirow{2}{*}{-} \\
\hline & without contact: 5 & without contact: 1 & \\
\hline \multirow{2}{*}{ Safety threat } & & with contact: 1 & \multirow{2}{*}{-} \\
\hline & without contact: 1 & without contact: 4 & \\
\hline Theft & without contact: 2 & without contact: 5 & - \\
\hline \multirow{2}{*}{ Sexual harassment } & & with contact: 3 & \multirow{2}{*}{ - } \\
\hline & without contact: 1 & without contact: 1 & \\
\hline \multirow{2}{*}{ Harassment/Annoyance } & \multirow{2}{*}{-} & with contact: 1 & - \\
\hline & & without contact: 4 & \\
\hline
\end{tabular}


Table 6: Number of participants not perceiving threats from examined out-groups

\begin{tabular}{|c|c|c|}
\hline discussed minority & $\begin{array}{l}\text { participants } \\
(N=42)\end{array}$ & $\begin{array}{l}\text { participants not } \\
\text { perceiving threat }\end{array}$ \\
\hline \multirow{2}{*}{ Roma } & with contact $(n=7)$ & $n=1$ \\
\hline & without contact $(n=7)$ & $n=1$ \\
\hline \multirow{2}{*}{ Slovak Hungarians } & with contact $(n=7)$ & $n=2$ \\
\hline & without contact $(n=7)$ & $n=3$ \\
\hline \multirow{2}{*}{ Immigrants } & with contact $(n=7)$ & $n=3$ \\
\hline & without contact $(n=7)$ & $n=2$ \\
\hline
\end{tabular}

Overall, almost each participant from the focus groups about the Roma feel an intergroup threat from this minority, and more than a half of participants from the discussions about Slovak Hungarians and immigrants from Arab and African countries perceive some threats from these out-groups. Few participants from each focus group do not perceive any type of threat from the minority discussed (see Table 6). We can also see that there is no difference in the threat perception based on direct contact with minority members.

\section{Conclusions and recommendations}

Based on our focus-group analyses, we identified several concerns, which we categorized into bigger threat categories and finally into four groups based on Stephan et al. (2009): symbolic group threats, realistic group threats, symbolic individual threats, and realistic individual threats. We identified some concerns, which to our knowledge have not been explored in previous threat literature, such as language barrier, sexual harassment, or annoyance. Among the identified threats there are also some which were mentioned in previous literature, but were not sufficiently researched in threat studies, such as theft, abuse of the social system, or lack of trust. Since we have explored several relevant concerns which are not covered by threat literature and threat scales, our main conclusion is that it is crucial to develop a new metric which allows researchers to fully understand and study the concerns of in-groups about different out-groups. The new metric could help to quantitatively investigate different threat types, their role for attitudes and emotions towards out-groups, and therefore in improving intergroup relations between groups. Our next step will hence be the development of a new measure for perceived intergroup threats.

Different out-groups pose different threats, therefore in prejudice reduction it is important to focus on those threats which are felt by the majority connected to a particular out-group. It seems that it is not adequate to perceive and study intergroup threats as one general factor.

In our study, participants perceived various concerns from immigrants from Arab and African coun- tries. Symbolic group threats concerned threats to their own culture and problems with cultural adaptation in Slovakia. There were also economic threats mentioned which were mainly related to the abuse of the social system in the state. These findings are consistent with Bahna \& Klobucký $(2015,2016)$. On the side of individual threats, trust issues appeared, but the most important individual threats were about safety (in line with the findings from Bahna \& Klobucký, 2015, 2016; Lášticová \& Andráščiková, 2016; Pétiová, 2016), more precisely an increase in criminality. Since realistic individual threats were perceived almost only by Slovaks in no contact with this minority, these concerns do not come from personal experience but from stereotypical portrayals of immigrants as criminals and terrorists.

The results about threats from the Roma felt by our respondents are in line with the findings from Kende et al. (2020), that Roma people pose several types of realistic individual threats - criminality and economic threats - beliefs of undeserved benefits, and symbolic group threats regarding a different culture and way of life. Most concerns were related to realistic threats, more precisely threats to personal safety, theft, sexual harassment, and annoyance/harassment. Dimitrova et al. (2015) confirmed that the perceived economic, symbolic, and safety threat posed by the Roma is closely related to negative attitudes toward this minority.

The Hungarian minority mostly poses symbolic threats: group and individual, and power threats. Symbolic group threats were related to the lack of language adaptation by the Slovak Hungarians, and symbolic individual threat concerned the language barrier between the groups. These finding are consistent with Gallová Kriglerová and Kadlečíková (2009), and MészárosováLamplová (2009), where Slovak Hungarians felt discrimination mainly because of speaking Hungarian and their Hungarian identity. According to our participants, the only issue in symbolic threats is linguistic. Power threats felt by young Slovaks were the threat to political power and power takeover due to the shared history between Slovakia and Hungary. Chmel (2004) stated that historical traumatization and different views of shared history are the sources of negative attitudes between the Slovak majority and Hungarian minority in Slovakia.

As the perception of threats from immigrants (and other minority groups) are the main cause of negative attitudes towards them (Esses et al., 2017; Yitmen \& Verkuyten, 2018), it is crucial to address this in order to improve intergroup attitudes and relations.

\section{Acknowledgement}

This research is a part of the VEGA 2/0127/19 and VEGA 1/0075/19 projects. The work of Dóra Belán was conducted during her doctoral studies at the Faculty of Social and Economic Sciences of Comenius University 
in Bratislava. There is no conflict of interest to declare in this study.

\section{Literature}

Arnett, J. J. (2004). Emerging adulthood: The winding road from the late teens through the twenties. Oxford University Press.

Bahna, M., Klobucký, R. (2015). Slovenská verejnost’ a utečenci $v$ decembri 2015. Tlačová správa Sociologického ústavu SAV. Retrieved 5. 12. 2020 from: http://www.sociologia.sav.sk/cms/ uploaded/2297_attach_tlacova_sprava_SU_SAV21122015.pdf

Bahna, M., Klobucký, R. (2016). Slovenská verejnost' a utečenecká kríza po roku: utečencov sa menej obávame, stále im však chceme pomáhat'len $v$ úplne nevyhnutných prípadoch. Tlačová správa Sociologického ústavu SAV. Retrieved 5. 12. 2020 from: http://www.sociologia.sav.sk/cms/ uploaded/2506_attach_tlacova_sprava_utecenci_2016.pdf

Benkovičová, L. (1995). Tolerancia a intolerancia v každodennom živote slovenskej spoločnosti optikou výskumu verejnej mienky. Sociológia, 27, 385-397.

Bieliková, M. a kol. (2013). Prejavy intolerancie a násilia u žiakov základných a stredných škôl na Slovensku. In R. Štefančík et al. Pravicový extrémizmus a mládež na Slovensku. Brno: Tribun EU.

Cakal, H., Hewstone, M., Guler, M., \& Heath, A. (2016). Predicting support for collective action in the conflict between Turks and Kurds: Perceived threats as a mediator of intergroup contact and social identity. Group Processes \& Intergroup Relations 19(6). https://doi.org/10.1177/1368430216641303

Chmel, R. (2004). Moje slovenské pochybnosti: texty z rokov 1991-2002. Bratislava: Kalligram.

Cohrs, J. C., Kielmann, S., Maes, J., \& Moschner, B. (2005). Effects of right-wing authoritarianism and threat from terrorism on restriction of civil liberties. Analyses of Social Issues and Public Policy (ASAP), 5(1), 263-276.

Cottrell, C. A., \& Neuberg, S. (2005). Different emotional reactions to different groups: A sociofunctional threat-based approach to "prejudice". Journal of Personality and Social Psychology, 88(5), 770-789.

Dimitrova, R., Buzea, C., Ljujic, V., \& Jordanov, V. (2015). Nationalistic attitudes and perceived threat determine Romaphobia among Bulgarian and Romanian Youth. Revista de Asistenta Sociala, 3, 33-47.

Esses, V. M., Hamilton, L.K., \& Gaucher, D. (2017). The Global Refugee Crisis: Empirical Evidence and Policy Implications for Improving Public Attitudes and Facilitating Refugee Resettlement. Social Issues and Policy Review, 11(1), 78-123.

Gallová Kriglerová, E., \& Kadlečíková, J. (2009). Kultúrna rozmanitost’ a jej vnímanie žiakmi základných škôl na Slovensku. Bratislava: Open Society Foundation.

Gallová-Kriglerová, E., \& Kadlečíková, J. (2012). Verejná mienka v oblasti pravicového extrémizmu: Výskumná správa. Bratislava: Nadácia otvorenej spoločnosti.

Goldston, J. A. (2002). Roma Rights, Roma Wrongs. Foreign Affairs, 81, 146-162.

Hutchison, P., Chihade, R., \& Puiu, A. A. (2018). Predictors of "The last acceptable racism": Group threats and public attitudes toward Gypsies and Travellers. Journal of Applied Social Psychology, 48(5), 237-247.

Jedinger, A., \& Eisentraut, M. (2020). Exploring the Differential Effects of Perceived Threat on Attitudes Toward
Ethnic Minority Groups in Germany. Front. Psychol., 10. https://doi.org/10.3389/fpsyg.2019.02895

Jetten, J., Spears, R., \& Postmes, T. (2004). Intergroup distinctiveness and Differentiation: A meta-analytic integration. Journal of Personality and Social Psychology, 86(6), 862-879.

Joffe, H., \& Yardley, L. (2004). Content and thematic analysis. Research methods for clinical and health psychology (56-68). London: Sage.

Kalmárová, V., Lášticová, B., Findor, A., \& Hruška, M. (2017). Aké vzdelávacie faktory súvisia s postojmi slovenských stredoškolákov a stredoškoláčok k menšinám? Správa z výskumu. Bratislava: Štátna školská inšpekcia.

Keil, T. F., Koschate, M., \& Levine, M. (2020). Contact Logger: Measuring everyday intergroup contact experiences in near-time. Behaviour Research Methods.

Kende, A., Hadarics, M., Bigazzi, S., Boza, M., Kunst, J. R., Lantos, N. A., Lášticová, B., Minescu, A., Pivetti, M., \& Urbiola, A. (2020). The last acceptable prejudice in Europe? Anti-Gypsyism as the obstacle to Roma inclusion. Group Processes \& Intergroup Relations. (advance online publication) https://doi.org/10.1177/1368430220907701

Kende, A., Hadarics, M., \& Lášticová, B. (2017). Anti-Roma attitudes as expressions of dominant social norms in Eastern Europe. International Journal of Intercultural Relations, 60, 12-27. https://doi.org/10.1016/j.ijintrel.2017.06.002

Kteily, N., Bruneau, E., Waytz, A., \& Cotterill, S. (2015). The ascent of man: Theoretical and empirical evidence for blatant dehumanization. Journal of Personality and Social Psychology, 109(5), 901-931.

Landmann, H., Gaschler, R., \& Rohmann, A. (2019). What is threatening about refugees? Identifying different types of threat and their association with emotional responses and attitudes towards refugee migration. EJSP Special Issue: The Social Psychology of Forced Migration and Refugee Integration, 49(7), 1401-1420.

Lášticová, B., \& Andraščiková, S. (2016). Sociálne reprezentácie Rómov a utečencov: analýza volných asociácií. In J. Kanovská Halamová, Ed., Komunitná psychológia na Slovensku 2016: zborník z 3. ročníka vedeckej konferencie Komunitná psychológia na Slovensku 2016 (53-59). Bratislava: Univerzita Komenského v Bratislave vo Vydavatelstve UK pre Ústav aplikovanej psychológie, FSEV UK.

Leach, C. W., Spears, R., Branscombe, N. R., \& Doosje, B. (2003). Malicious pleasure: Schadenfreude at the suffering of another group. Journal of Personality and Social Psychology, 84(5), 932-943.

LeVine, R. A., Campbell, D. T. (1972). Ethnocentrism: Theories of conflict, ethnic attitudes, and group behavior. John Wiley \& Sons.

Ljujic, V., Vedder, P., Dekker, H., \& van Geel, M. (2012). Romaphobia: A unique phenomenon? Romani Studies, 22(2), 141-152.

Macháček, L. (2013). Vzt’ah slovenských občanov a mládeže k pravicovému extrémizmu. In R. Štefančík et al. Pravicový extrémizmus a mládež na Slovensku (37-92). Brno: Tribun EU.

Mészárosová-Lamplová, Z. (2009). Slováci a Madari na južnom Slovensku: možnosti uplatňovania jazykových práv, 159-169. In K. Petőcz. (Ed.) Národný populizmus na Slovensku a slovensko-madiarské vztahy 2006-2009 (pp. 159-170). Šamorín: Forum Institute. 
Minescu, A., Hagendoorn, L., \& Poppe, E. (2008). Types of Identification and Intergroup Differentiation in the Russian Federation. Journal of Social Issues, 64(2). https://doi.org/10.1111/j.1540-4560.2008.00564.x

Pétiová, M. (2016). Prejavy extrémizmu v školskom prostredí $z$ pohladu žiakov základných a stredných škôl. Bratislava: Centrum vedecko-technických informácií SR.

Petrova, D. (2003). The Roma: Between a Myth and the Future. Social Research, 70, 111-61.

Richardson, J. (2006). Talking about Gypsies: The Notion of Discourse as Control. Housing Studies, 21(1), 2-32.

Riek, B. M., Mania, E., \& Gaertner, S. (2006). Intergroup Threat and Outgroup Attitudes: A Meta-Analytic Review. Personality and Social Psychology Review, 10(4), 336-53.

Schlueter, E., \& Scheepers, P. (2010). The relationship between outgroup size and anti-outgroup attitudes: A theoretical synthesis and empirical test of group threat- and intergroup contact theory. Social Science Research, 39(2), 285-295.

Schneider, S. L. (2008). Anti-Immigrant Attitudes in Europe: Outgroup Size and Perceived Ethnic Threat. European Sociological Review, 24(1), 53-67.

Slovíková, M. (2012). Vzor tolerantného správania mladých ludí $v$ rodine a $v$ škole: výskum názorov a postojov žiakov. Bratislava: Ústav informácií a prognóz školstva.

Special Eurobarometer: Discrimination in the EU (including LGBTI). (2019). EU Open Data Portal. Retrieved from: https://data.europa.eu/euodp/en/data/dataset/ S2251_91_4_493_ENG

Stephan, W. G. (2014). Intergroup Anxiety: Theory, Research, and Practice. Personality and Social Psychology Review, 18(3). https://doi.org/10.1177/1088868314530518

Stephan, W. G. et al. (2002). The Role of Threats in the Racial Attitudes of Blacks and Whites. Personality and Social Psychology Bulletin, 28(9), 1242-1254.
Stephan, W. G., \& Stephan, C. W. (2000). An integrated threat theory of prejudice. In S. Oskamp (Ed.), Reducing Prejudice and Discrimination (23-45). Mahwah, NJ: Lawrence Erlbaum Associates.

Stephan, W. G., Renfro, C. L., Esses, V. M., Stephan, C. W., $\&$ Martin, T. (2005). The effects of feeling threatened on attitudes toward immigrants. International Journal of Intercultural Relations, 29(1), 1-19.

Stephan, W. G., Ybarra, O., \& Rios Morrison, K. (2009). Intergroup threat theory. In T. Nelson (Ed.), Handbook of prejudice (43-59). Mahwah, NJ: Lawrence Erlbaum Associates. Stroschein, S. (2018). Understanding ethnic minorities in Eastern Europe. In A. Fagan, \& P. Kopecký (Eds.), The Routledge handbook of East European Politics (213-224). London: Routledge.

Van der Linden, M., \& Jacobs, L. (2016). The impact of cultural, economic, and safety issues in Flemish television news coverage (2003-13) of North African immigrants on perceptions of intergroup threat. Ethnic and Racial Studies, 40(15), 2823-2841.

Vašečka, M. (2002). Vztah majority k Rómom. In M. Vašečka (Ed.), Čačipen pal o Roma. Súhrnná správa o Rómoch na Slovensku (s. 335-351). Bratislava: Inštitút pre verejné otázky.

Yitmen, S., \& Verkuyten, M. (2018). Feelings toward refugees and non-Muslims in Turkey: The roles of national and religious identifications, and multiculturalism. Journal of Applied Social Psychology, 48(2), 90-100.

Zárate, M.A., Garcia, B., Garza, A.A., \& Hitlan, R. (2004). Cultural Threat and Perceived Realistic Group Conflict as Dual Predictors of Prejudice. Journal of Experimental Social Psychology, 40(1), 99-105. 